\title{
THE EFFECT OF SILVICULTURAL TREATMENT ON STAND GROWTH OF LOGGED-OVER FOREST IN SOUTH PAPUA
}

\author{
Relawan Kuswandi ${ }^{*}$
}

Received : 28 September 2012, Accepted : 7 April 2014

\begin{abstract}
Forest stand structure could be used as one of the variables in deciding the possibility to harvest forest product. On logged-over forests, data and information over stand structure could become the basis for decision making for harvesting. To measure and analyze yield on logged-over forest, each forest management unit (IUPHHK) is obligated to establish Permanent Sample Plots (PSPs) for monitoring the growth and yield of the managed stand. In some of the plots, maintenances and thinning treatments are applied while other plots are not treated. The results, after several years of observations, showed that there was a difference in stand structure (tree number) of each diameter class both in plots with treatment and without treatment. The rate of in-growth, up-growth and mortality varied between plots without and with treatment in each diameter class and length of time after harvesting. The average diameter increment of trees in the stands of the untreated plots was higher $\left(0.60 \mathrm{~cm} \mathrm{yr}^{-1}\right)$ compared to the treated plots $\left(0.55 \mathrm{~cm} \mathrm{yr}^{-1}\right)$.
\end{abstract}

Keywords: Structure of stands, logged-over forests, natural forests, increment

\begin{abstract}
ABSTRAK
Kondisi tegakan hutan dapat digunakan sebagai salah satu indicator dalam menentukan adanya kemungkinan untuk penentuan penebangan pada hutan bekas tebangan. Hal ini dapat dilakukan dengan menganalisis kondisi tegakan tersebut dengan menggunakan data dari pengukuran periodic yang dilakukan pada petak ukur permanen (PUP). Pendirian PUP dilakukan oleh pemegang IUPHHK dengan tujuan untuk monitoring pertumbuhan tegakan setelah penebangan. Penelitian ini dilakukan dengan menggunakan PUP yang dilakukan perlakuan penjarangan dan PUP yang tidak ada perlakuan silvikultur (control). Hasil penelitian menunjukan bahwa setelah penebangan, terdapat perbedaan struktur tegakan pada kedua tipe PUP tersebut dalam hal in-growth, up-growth dan mortality. Selanjutnya pada pertumbuhan tegakan pada PUP tanpa perlakuan lebih tinggi yaitu $0,60 \mathrm{~cm}$ per tahun, sedangkan untuk tegakan pada PUP perlakuan adalah $0,55 \mathrm{~cm}$ per tahun.
\end{abstract}

Kata kunci: Struktur tegakan, hutan bekas tebangan, hutan alam, riap

\footnotetext{
${ }^{1}$ Manokwari Forestry Research Institute, Jl. Inamberi, Susweni PO BOX 159, Manokwari 98313-Papua Barat Tel. (0986) 213437

*Corresponding author: r_kuswandi@yahoo.co.id
} 


\section{INTRODUCTION}

Forest management practice (e.g. logging) will provide the ecological impact of changes in the composition and structure of the residual stand in the logged-over forest. Information about the structure of the stand is considered important because in terms of economic factors, the structure of the stand will determine the minimum standing stock of the timber that must be available for good growth, while in terms of ecological factors, the structure of the stand can give an idea about the ability of the stand to regenerate (Suhendang, 1994). Changes in forest stand structure or growth of stand can be affected by external and internal factors, such as climate, soil fertility, pest-diseases as well as genetic origin of trees.

Some important components of the stand growth are ingrowth, upgrowth, and mortality. Ingrowth is defined as trees that grow to a class or stage of growth of the smallest diameter measured during a certain time. Upgrowth is defined as trees that grow to the next diameter class, and mortality is defined as trees that have died within a period of time. Although the mortality reduces the tree basal area of the stand, but the larger growing space will increase the growth of the trees of the residual stand (Buongiorno and Michie, 1980; Golley, 1983; Waring and Schlesinger, 1985; Davis and Johnson, 1987).

To monitor the dynamic of standing stock and stand growth of the logged-over forests, permanent sample plots (PSPs) have to be established in each forest management unit (e.g. forest concessions or logging companies) as stated in the Minister of Forestry Decree No.237/Kpts-II/1995. Therefore, data collected from PSPs providing temporal data of how remaining stands respond after harvesting. The remaining stands can grow naturally faster or slower depending on the growth rate and its response to canopy openness resulting from logging activity. Lal (1960) stated that growth of the remaining stand can be influenced positively by implementing silvicultural treatments. A study conducted by Krisnawati and Wahjono (2010) in logged-over forests in West Kalimantan has shown that growth rate of the remaining stands increased two folds with silvicultural treatment compared to growth rate of the remaining stands without silvicultural treatment.

In logged-over forests in Papua, some PSPs have been established by logging companies. However, there is no complete information in relation to how remaining stands respond to silvicultural treatment in logged-over forest in Papua. This study aims to examine the effect of silvicultural treatments on stand growth of logged-over forests in South Papua.

\section{MATERIAL AND METHOD}

\section{A. Research Sites}

The experiment was conducted on the PSPs series located in the IUPHHK of PT. Tunas Sawaerma, Boven Digul District, Papua Province (Figure 1). Size of each PSP is 100 x $100 \mathrm{~m}$. The PSPs are located in logged-over forest, i.e. Annual Work Plan (RKT) Block of 2004, Five-yearly Work Plan (RKL) Block IV of 2004 to 2009, and Logging Block E 55. The topography is relatively flat to undulating with a slope of $0-8 \%$ and elevation of $20-50 \mathrm{~m}$ above sea level (a.s.l). Soil types found in the second area are ultisol, gray brown podzolic, red yellow podzolic and alluvial. The climate is classified as type A with an average annual rainfall of 4196 $\mathrm{mm}$. Number of rainy days per month ranges between 11 and 24 days.

\section{B. Material}

The material used in this study was measurement data from six PSPs established in logged-over forest of PT. Tunas Sawaerma which have been annually measured from 2005 to 2011. The measurements were conducted for all trees growing in PSPs which had a diameter at breast height $(\mathrm{DBH})$ of $10 \mathrm{~cm}$ or larger. Silvicultural treatment was applied in PSP 1, PSP 2 and PSP 3 by cutting trees with DBH below $10 \mathrm{~cm}$ and lianas around future crop 


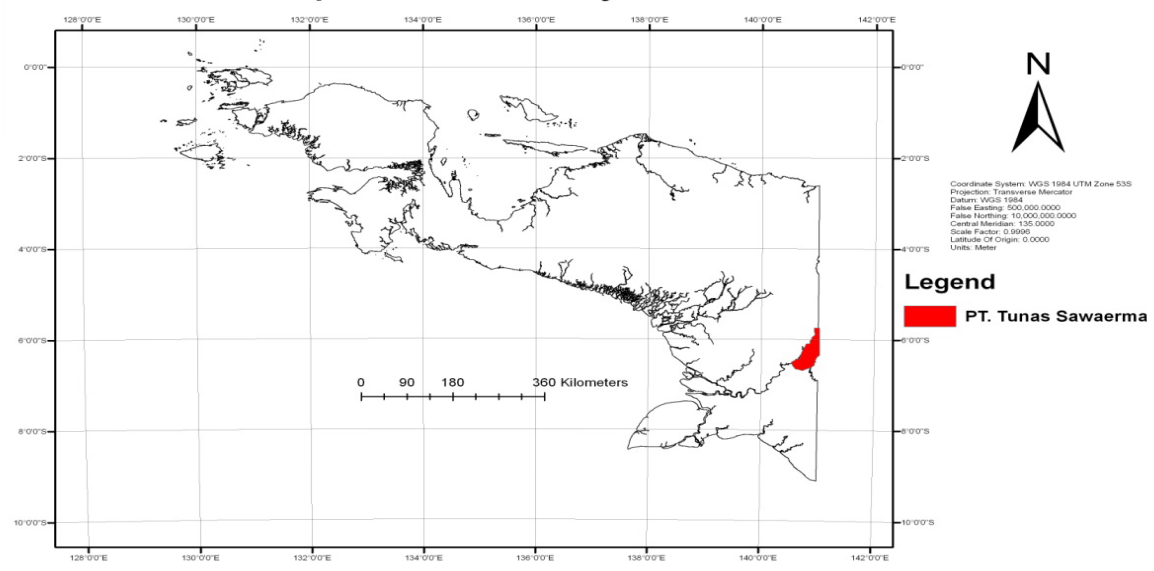

Figure 1. Map of the study area of PT. Tunas Sawaerma, Boven Digul

trees; while PSP 4, PSP 5 and PSP 6 were as control plots with no silvicultural treatment.

\section{Data Processing}

Diameter of the trees in the plots was grouped using $10 \mathrm{~cm}$ intervals as diameter classes from $10 \mathrm{~cm}$ to $50 \mathrm{~cm}$. In each plot, ingrowth, upgrowth, mortality and diameter increment of stands were analyzed by diameter class. The calculations were as follow:

\section{Ingrowth}

Ingrowth is defined as the proportion of new trees growing to the smallest diameter class $(10-19 \mathrm{~cm})$. The ingrowth rate was calculated by the following formula :

where I : Ingrowth rate; ri : Number of new trees growing to the smallest diameter

$$
I=\frac{\sum r_{i}}{\sum N_{i}} x 100 \%
$$

class at year $\mathrm{i}$; and $\mathrm{N}_{\mathrm{i}}$ : Number of trees in the smallest diameter class at year $\mathrm{i}$.

\section{Upgrowth}

Upgrowth is defined as the proportion of trees that grow up to the next larger diameter class. Upgrowth rate was calculated by the following formula: where $\mathrm{U}_{\mathrm{i}}$ : upgrowth rate of the diameter class $i$; $u_{i j}$ : Number of trees growing to the $U_{i}=\frac{\sum u_{j}}{\sum N_{j}} x 100 \%$

next diameter class at year $\mathrm{i} ; \mathrm{N}_{\mathrm{ij}}$ : Number of trees in diameter class iat year $\mathrm{j}$

\section{Mortality}

Mortality is defined as the proportion of dead trees within the measurement period. The mortality rate was calculated by the following formula:

where $\mathrm{M}_{\mathrm{i}}$ : Mortality rate for diameter class $\mathrm{i} ; \mathrm{u}_{\mathrm{ij}}$ : Number of died trees in diameter class

$M_{i}=\frac{\sum m_{j}}{\sum N_{j}} x 100 \%$

$i$ at year $j ; N_{i j}$ : Number of trees in diameter class $i$ at year $j$

\section{Increment}

Current Annual Increment (CAI) of diameter was calculated by the following formula:

$\mathrm{CAI}=\mathrm{D}_{\mathrm{t}+1}-\mathrm{D}_{\mathrm{t}}$

where $: \mathrm{D}_{\mathrm{t}}=$ diameter at year $\mathrm{t}, \mathrm{t}=$ year of measurement. 


\section{Data Analysis}

A stand structure model was developed for each year of measurement. The model used is the stand structure model developed by Meyer (1952):

$$
\mathrm{N}_{\mathrm{t}}=\mathrm{N}_{\mathrm{o}} \mathrm{e}^{-\mathrm{kD}}
$$

where $\mathrm{N}_{\mathrm{t}}$ : Number of trees per ha per diameter class; D : Diameter; $\mathrm{k}$ : constant; $\mathrm{N}_{\mathrm{o}}$ : Number of trees in the smallest diameter class; and e : natural logarithm.

\section{RESULT AND DISCUSSION}

\section{A. Stand Structures}

Stands in PSPs with or without treatment are growing in more or less in the same abiotic condition as mentioned in the previous part. Therefore, variation of stand structures in this study was expected as result of variation of diameter class, silvicultural treatment as well as time.

The stand structure is, furthermore, the physical and temporal distribution of trees in stands by type, vertical and horizontal distribution patterns, size of the trees, including canopy volume, leaf area index, stem, stem cross section, age of a tree or a combination of these (Oliver and Larson, 1990). Since the age of the stand is unknown and cannot be determined precisely in natural forest, then the diameter distribution of the trees per hectare can be used to explain the stages of tree growth (Meyer et al., 1961).

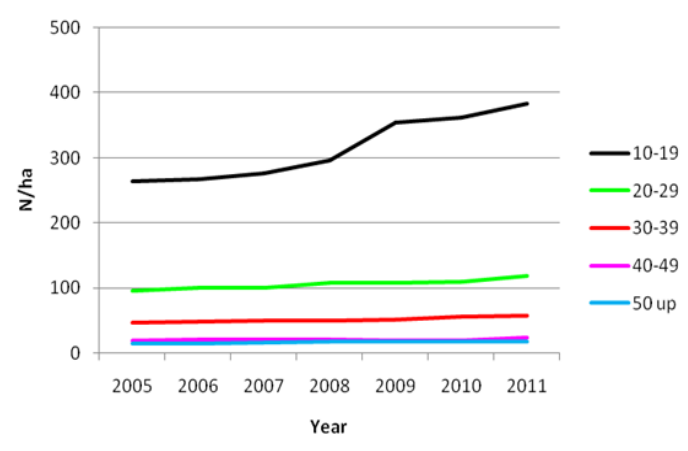

(a)
The number of trees per diameter class from each PSP (both with and without treatment) after a few years of measurement is presented in Figure 2.

Figure 2 shows that there are differences in the number of trees per PSPs without and with treatment after several years of measurements based on the diameter class of the stand. In the diameter class of $10-19 \mathrm{~cm}$, the number of trees in PSPs without treatment increased with time, but on the other hand, it has decreased on the PSPs with treatment. The decrease is a result of liberation treatment in these PSPs. The liberation was done by cleaning small trees and liana around future trees. Intensity of liberation was high in which $75 \%$ of small trees and liana was cleaned in this treatment. Small trees of commercial species in the plot could not actually compete with other species that were not commercial species. Therefore, only a few number of small trees entered in the smallest diameter class $(10-19 \mathrm{~cm})$. Then, it predictably resulted in slow growth and high mortality of small trees causing low ingrowth as presented in Figure 2 (b).

In contrast, the number of trees with $\mathrm{DBH}$ above $20 \mathrm{~cm}$ in PSPs both with and without treatment increased every year. The increase of PSPs with treatment was higher than the increase of PSPs without treatment. The higher increase was in consequence of higher ingrowth of future trees because liberation has reduced competition between future trees and

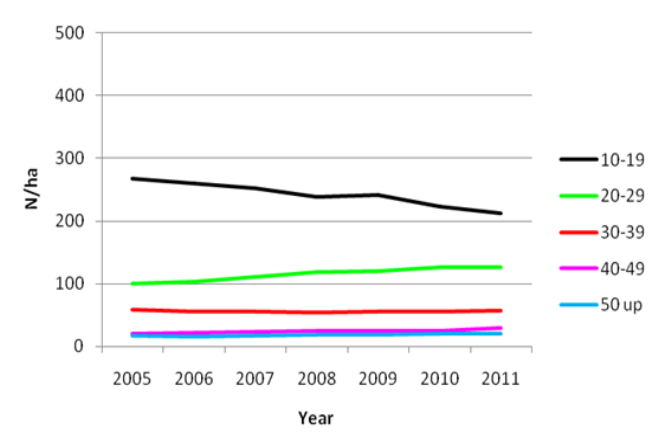

(b)

Figure 2. Number of trees per hectare based on diameter classes in PSPs: (a) PSPs without treatment (b) PSPs with treatment 


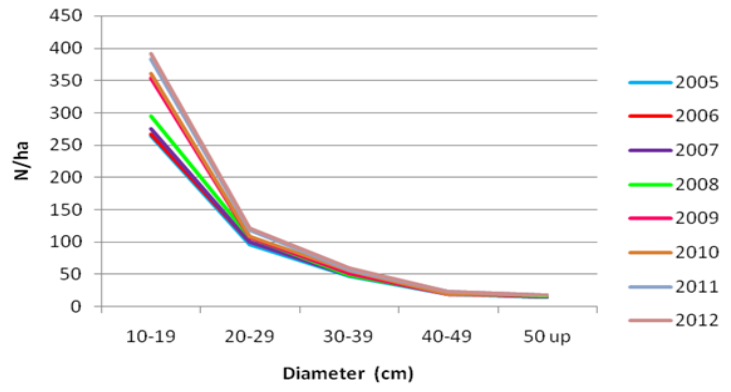

(a)

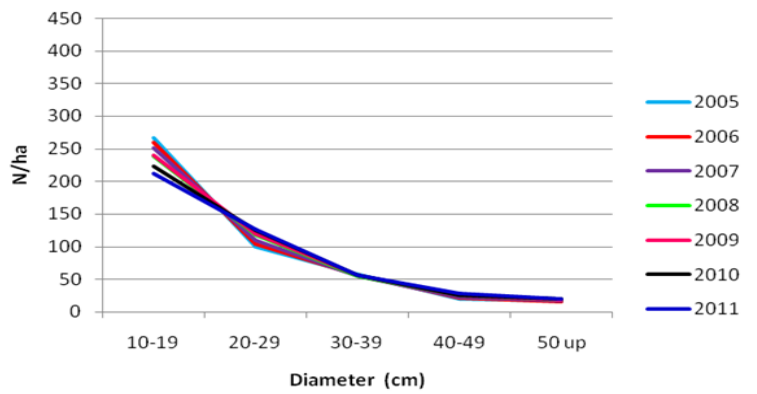

(b)

Figure 3. The stand structure of PSPs:(a) without treatment (b) with treatment

Table 1. Stand structure model of PSPs (with and without treatments) after several years of measurements

\begin{tabular}{ccccc}
\hline Time of & \multicolumn{2}{c}{ PSPs without treatment } & \multicolumn{2}{c}{ PSPs with treatment } \\
\cline { 2 - 5 } $\begin{array}{c}\text { Measurement } \\
\text { After cutting }\end{array}$ & Model of stand structure & $\mathrm{R}^{2}(\%)$ & Model of stand structure & $\mathrm{R}^{2}(\%)$ \\
\hline $\mathrm{t}+1$ & $\mathrm{~N}=462.9 \mathrm{e}^{-0.73 \mathrm{D}}$ & 97.0 & $\mathrm{~N}=475.2 \mathrm{e}^{-0.71 \mathrm{D}}$ & 96.4 \\
$\mathrm{t}+2$ & $\mathrm{~N}=474.8 \mathrm{e}^{-0.73 \mathrm{D}}$ & 97.7 & $\mathrm{~N}=469.4 \mathrm{e}^{-0.71 \mathrm{D}}$ & 97.6 \\
$\mathrm{t}+3$ & $\mathrm{~N}=485.1 \mathrm{e}^{-0.73 \mathrm{D}}$ & 97.3 & $\mathrm{~N}=462.3 \mathrm{e}^{-0.69 \mathrm{D}}$ & 98.4 \\
$\mathrm{t}+4$ & $\mathrm{~N}=509.3 \mathrm{e}^{-0.73 \mathrm{D}}$ & 96.1 & $\mathrm{~N}=433.0 \mathrm{e}^{-0.66 \mathrm{D}}$ & 98.3 \\
$\mathrm{t}+5$ & $\mathrm{~N}=584.8 \mathrm{e}^{-0.76 \mathrm{D}}$ & 94.3 & $\mathrm{~N}=439.6 \mathrm{e}^{-0.66 \mathrm{D}}$ & 98.1 \\
$\mathrm{t}+6$ & $\mathrm{~N}=604.2 \mathrm{e}^{-0.76 \mathrm{D}}$ & 94.5 & $\mathrm{~N}=416.3 \mathrm{e}^{-0.64 \mathrm{D}}$ & 97.9 \\
$\mathrm{t}+7$ & $\mathrm{~N}=664.7 \mathrm{e}^{-0.78 \mathrm{D}}$ & 96.6 & $\mathrm{~N}=392.7 \mathrm{e}^{-0.61 \mathrm{D}}$ & 98.6 \\
\hline
\end{tabular}

small trees. As a result, the future trees were not suppressed when they were growing.

The average stand structure of PSPs with and without treatment during several years of measurements can be seen in Figure 3.

Based on the form of stand structure, stand structure curves can be generated by using the negative exponential equation as shown in Table 1.

Table 1 shows that the general model of forest stand structure on PSPs follows the model of natural forest's stand structure, that is the reversed-J shape. Thus, the number of trees decreases with increasing diameter, in both PSPs with and without treatment. However, the specific form of the reversed-J shape, i.e. the steepness can vary from one stand to another. Steepness depends on the diameter class distribution and the smallest and largest number of trees in each diameter class (Meyer et al., 1961; Davis and Jonson, 1987). The position of the curve on the abscissa is associated with the largest-diameter trees; density of residual stand determines the position of the curve between the axes, and the slope of the curve is determined by the distribution of the diameter classes (Marsono, 1987). The suitability of the natural forest stand structure model is confirmed by the high significance (R2) level ranging from $94.3 \%$ to $97.7 \%$ on the PSPs without treatment and $96.4 \%$ to $98.6 \%$ on the PSPs with treatment. Thus the stand structure model $\mathrm{N}=\mathrm{N}_{0} e^{-\mathrm{kD}}$ is acceptable for both PSPs without treatment and with treatment at each measurement time.

\section{B. Stand Growth}

Stand growth is the change in the size such as diameter and height of stands that occur during a specific time period. In forest management, the stand growth can be also expressed as increment in terms of stand volume $\left(\mathrm{m}^{3} \mathrm{ha}^{-1}\right.$ year $\left.{ }^{-1}\right)$ which is used to show the maximum amount of timber volume that 


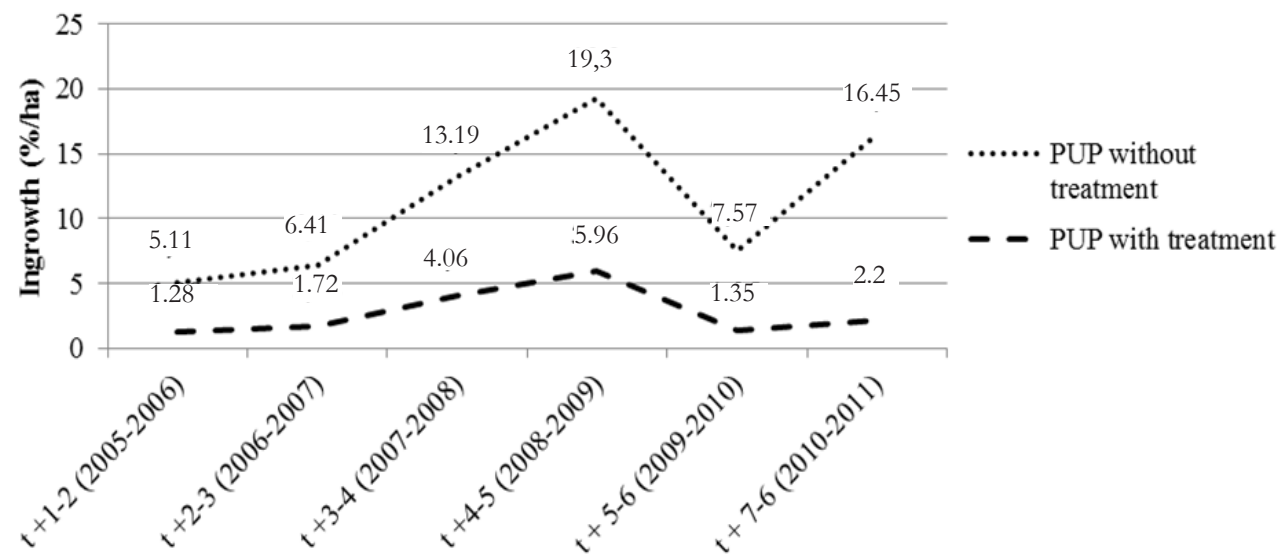

Figure 4. Ingrowth rate of PSPs without treatment and PSPs with treatment

can be harvested in the period (year) or better known as annual allowable cut (AAC) (David and Jonson, 1987; Vanclay, 1995).In this study, we present ingrowth, upgrowth, and mortality as driving factors which contribute to the stand growth.

\section{Ingrowth}

The rate of ingrowth in both PSPs without and with treatment can be seen in Figure 4 . Figure 4 shows that the rate of ingrowth was higher in PSPs without treatment in all years of observation. This is caused by the high intensity of treatment applied early to the PSPs with treatment resulting in significantly reduced number of trees with diameter below $10 \mathrm{~cm}$ which led to a small number of recruited trees in the plots.

In general, ingrowth of both PSPs with and without treatment increases several years after logging. It can be seen that the highest rate of ingrowth occurred in the fifth year on the PSPs either without treatment (19.30\%) and on PSPs with treatment $(5.96 \%)$. Increase of ingrowth in this logged-over forest is owing to more gap in the canopy, which stimulates more light reaching the understory. In addition, microclimatic circumstance is recovering after several years, which influence small trees to grow faster (Golley, 1983).

With the increasing stand density, basal area will increase and ingrowth rate may drop in subsequent years due to competition between trees.

\section{Upgrowth}

Upgrowth pace during several years of observations in PSPs can be seen in Figure 5. Figure 5 shows that the rate of upgrowth in the diameter classes vary from each time of the observation as well as between PSPs. The highest rate of upgrowth was in diameter class 40-49 $\mathrm{cm}$ both in PSPs without and with treatment. The rate of upgrowth in plots without treatment tended to increase with time after cutting in all diameter classes except in the diameter class $\geq 50 \mathrm{~cm}$ which tended to decline. This means upgrowth is higher with increasing number of trees (stand density) (Buongiorno and Michie, 1980; Buongiorno et al, 1995; Kofod, 1982; Oliver and Larson, 1990).This condition explains the phenomenon of growth in logged-over forest. Gap of canopy after harvesting stimulates the tree growth thereby increasing the density of the stands (Davis and Johnson, 1987). Moreover, trees compete with other trees in order to be dominant trees so the trees can receive more light (Folley, 1983).

In the PSPs with treatment, there was a fluctuation of upgrowth rate in all classes. The highest upgrowth appeared in the fourth year after cutting in all diameter classes, and then declined, but tended to increase again in the following years. This is in line with the reduction in the number of trees (stand density). Upgrowth varied in each diameter 


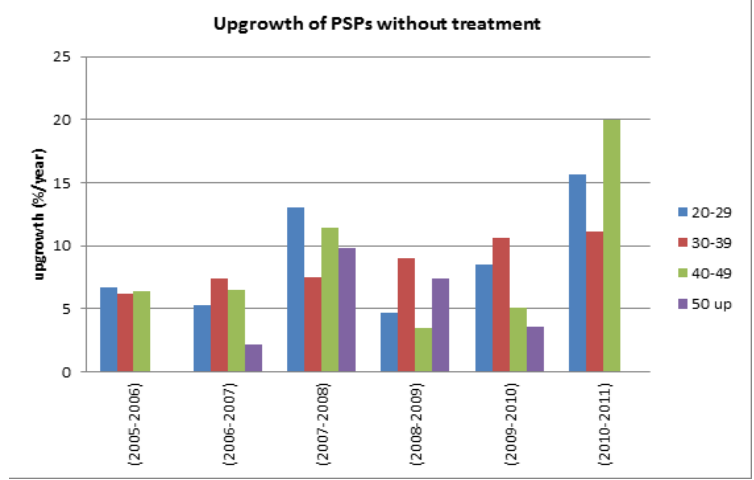

(a)

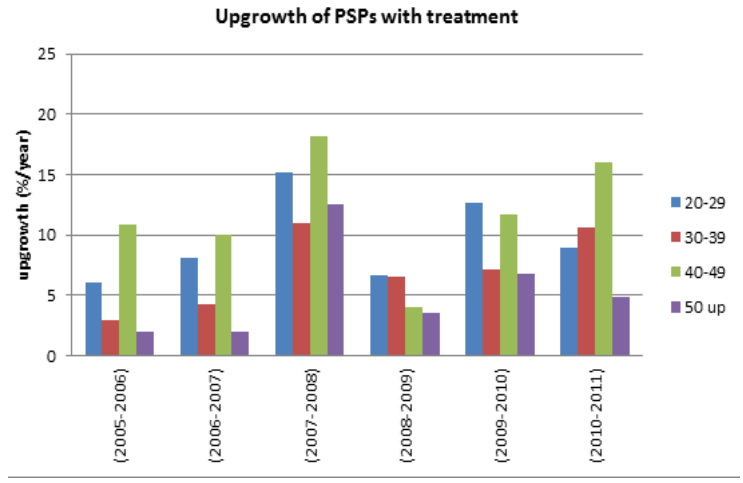

(b)

Figure 5. The rate of upgrowth in PSPs (a) without treatment (b) with treatment

Table 2. Mortality rate of PSPs without and with treatment based on diameter classes

\begin{tabular}{|c|c|c|c|c|c|c|}
\hline \multirow{2}{*}{$\begin{array}{c}\text { Diameter } \\
\text { Class } \\
(\mathrm{cm})\end{array}$} & \multicolumn{6}{|c|}{ PSPs without treatment (\%) } \\
\hline & $\begin{array}{c}\mathrm{t}_{+1-2} \\
(2005-2006)\end{array}$ & $\begin{array}{c}\mathrm{t}_{+2-3} \\
(2006-2007)\end{array}$ & $\begin{array}{c}\mathrm{t}_{+3-4} \\
(2007-2008)\end{array}$ & $\begin{array}{c}\mathrm{t}_{+4-5} \\
(2008-2009)\end{array}$ & $\begin{array}{c}t_{+5-6} \\
(2009-2010)\end{array}$ & $\begin{array}{c}t_{+6-7} \\
(2010-2011)\end{array}$ \\
\hline $10-19$ & 1.5 & 1.3 & 1.7 & 0.9 & 1.4 & 2.4 \\
\hline $20-29$ & 0.0 & 2.0 & 2.2 & 0.3 & 1.2 & 2.5 \\
\hline $30-39$ & 1.4 & 2.7 & 4.8 & 1.3 & 1.2 & 2.4 \\
\hline $40-49$ & 0.0 & 6.6 & 3.3 & 1.7 & 0.0 & 5.7 \\
\hline$\geq 50$ & 0.0 & 0.0 & 0.0 & 1.9 & 1.8 & 5.8 \\
\hline & \multicolumn{6}{|c|}{ PSPs with treatment $(\%)$} \\
\hline $\begin{array}{c}\text { Diameter } \\
\text { Class } \\
(\mathrm{cm}) \\
\end{array}$ & $\begin{array}{c}t_{+1-2} \\
(2005-2006) \\
\end{array}$ & $\begin{array}{c}t_{+2-3} \\
(2006-2007) \\
\end{array}$ & $\begin{array}{c}t_{+3-4} \\
(2007-2008)\end{array}$ & $\begin{array}{c}t_{+4-5} \\
(2008-2009) \\
\end{array}$ & $\begin{array}{c}t+5-6 \\
(2009-2010) \\
\end{array}$ & $\begin{array}{c}t_{+6-7} \\
(2010-2011)\end{array}$ \\
\hline $10-19$ & 1.8 & 0.8 & 2.4 & 1.7 & 2.3 & 1.9 \\
\hline $10-29$ & 1.0 & 1.5 & 2.8 & 2.5 & 4.8 & 3.4 \\
\hline $30-39$ & 2.4 & 1.2 & 2.5 & 1.8 & 2.4 & 1.2 \\
\hline $40-49$ & 1.6 & 0.0 & 2.6 & 4.0 & 2.6 & 1.2 \\
\hline$\geq 50$ & 4.1 & 0.0 & 1.8 & 1.8 & 3.4 & 1.64 \\
\hline
\end{tabular}

class both in PSPs with treatment and in PSPs without treatment as shown proportionally in Figure 5 .

\section{Mortality}

Magnitude of the rate of mortality in PSPs without treatment and PSPs with treatment can be seen in Table 2. Table 2 above shows that the rate of mortality varied in the diameter class, with the time between the observation and treatment. In PSPs without treatment the highest mortality rate occurred in diameter class $40-49 \mathrm{~cm}$ in the third year after logging, it was $6.6 \%$ and then decreased in the following year and then rose in the eighth year by $5.7 \%$. Mortality rate of trees with diameter $\geq 50 \mathrm{~cm}$ tended to increase in line with the length of the time after harvesting. This was a result of logging and skidding which moderately damaged the canopy, trunks and buttress of the tree. In the PSPs with treatment the highest mortality rate occurred in diameter class 20 $30 \mathrm{~cm}$ which was $4.8 \%$. The diameter class has increased in mortality rate in line with the length of time after logging. This difference is caused by differences in response to the disturbances caused by the logging (Golley, 1983). Extreme changes in micro-climatic conditions after logging and the damage caused by logging affected the young trees more so that the small size trees die relatively faster than trees with larger diameter (Golley, 1983; Schulte, 1996; Waring and Schlesinger, 1985). The diversity of the high mortality may also not be separated from the fact that the death 
Table 3. Average current annual increment (CAI) in various diameter classes

\begin{tabular}{|c|c|c|c|c|c|c|c|}
\hline \multirow{2}{*}{$\begin{array}{c}\text { Class } \\
\text { Diameter }\end{array}$} & \multicolumn{7}{|c|}{ Plot PSPs without treatment } \\
\hline & $\begin{array}{c}t_{+1-2} \\
(2005-2006)\end{array}$ & $\begin{array}{c}\mathrm{t}_{+2-3} \\
(2006-2007)\end{array}$ & $\begin{array}{c}\mathrm{t}_{+3-4} \\
(2007-2008)\end{array}$ & $\begin{array}{c}t_{+4-5} \\
(2008-2009)\end{array}$ & $\begin{array}{c}t_{+5-6} \\
(2009-2010)\end{array}$ & $\begin{array}{c}t_{+6-7} \\
(2010-2011)\end{array}$ & Average \\
\hline $10-19$ & 0.41 & 0.52 & 0.80 & 0.59 & 0.73 & 0.85 & 0.65 \\
\hline $20-29$ & 0.37 & 0.39 & 0.84 & 0.46 & 0.56 & 0.76 & 0.56 \\
\hline $30-39$ & 0.43 & 0.36 & 0.99 & 0.41 & 0.50 & 0.84 & 0.59 \\
\hline $40-49$ & 0.40 & 0.46 & 0.89 & 0.52 & 0.62 & 0.74 & 0.60 \\
\hline$\geq 50$ & 0.48 & 0.37 & 0.89 & 0.51 & 0.51 & 0.89 & 0.61 \\
\hline Average & 0.42 & 0.42 & 0.88 & 0.50 & 0.58 & 0.81 & 0.60 \\
\hline \multirow{2}{*}{$\begin{array}{c}\text { Class } \\
\text { Diameter }\end{array}$} & \multicolumn{7}{|c|}{ Plot PSPs with treatment } \\
\hline & $\begin{array}{c}t_{+1-2} \\
(2005-2006) \\
\end{array}$ & $\begin{array}{c}\mathrm{t}^{+2-3} \\
(2006-2007)\end{array}$ & $\begin{array}{c}t_{+3-4} \\
(2007-2008)\end{array}$ & $\begin{array}{c}t_{+4-5} \\
(2008-2009)\end{array}$ & $\begin{array}{c}t+5-6 \\
(2009-2010)\end{array}$ & $\begin{array}{c}\mathrm{t}_{+6-7} \\
(2010-2011)\end{array}$ & Average \\
\hline $10-19$ & 0.40 & 0.42 & 0.69 & 0.40 & 0.56 & 0.63 & 0.52 \\
\hline $20-29$ & 0.38 & 0.39 & 0.85 & 0.39 & 0.67 & 0.75 & 0.57 \\
\hline $30-39$ & 0.39 & 0.41 & 0.90 & 0.45 & 0.67 & 0.80 & 0.60 \\
\hline $40-49$ & 0.51 & 0.29 & 0.79 & 0.36 & 0.50 & 0.71 & 0.53 \\
\hline$\geq 50$ & 0.40 & 0.39 & 0.78 & 0.46 & 0.64 & 0.68 & 0.56 \\
\hline Average & 0.42 & 0.38 & 0.80 & 0.41 & 0.61 & 0.72 & 0.55 \\
\hline
\end{tabular}

of trees in a stand is a process that is complex and relatively difficult to predict because of the many interacting factors (Waring, 1987).

\section{Stand Increment}

Diameter increment is one important component that determines the increment in volume. The stand increment depending on diameter and height growth. In this study, we used Current Annual Increment (CAI), Periodic Annual Increment (PAI), and Mean Annual Increment (MAI). CAI is the increment in the current year, the PAI is the increment in one time period while the MAI is the increment on average (per year) that occurs during a certain time period (Prodan, 1968).

The average Current Annual Increment (CAI) on PSPs without and with treatment after several years of measurement can be seen in Table 3. Table 3 shows that there is a difference in the CAI of diameters in both PSPs without and with treatments. In PSPs without treatment, the highest CAI was in the diameter class $10-19 \mathrm{~cm}$ (equal to $0.65 \mathrm{~cm}$ per year). This is caused by high ingrowth of pioneer species. In addition, gap in the canopy due to felling of trees encouraged the growth of small trees while on the PSPs with treatment the highest
CAI was in the diameter class $30-39 \mathrm{~cm}(0.60$ $\mathrm{cm}$ per year). The highest CAI in the diameter class 30-39 was due to open space resulting from logging.

Average current annual increment (CAI) on PSPs without treatment was higher than on PSPs with treatment. The low CAI on PSPs with intensive treatment was caused by the treatment given to cleaning off the stand diameter $<10$ $\mathrm{cm}$. Besides, caused by the density of stands, the higher CAI in PSPs without treatment is owing to differences in type and environmental conditions. Tree growth is largely determined by the interaction of three factors: heredity, environment and silvicultural techniques (Kramer and Koslowski, 1960). Lal (1960) mentioned that the factors that influence the size of the increment of a stand is an act of silviculture, type and quality of place to grow. The external factors like edaphic and climatic conditions also influence the growth of the stand. Undaharta et al. (2008) mentioned that the stand increment is also influenced by stand density, soil type and fertility. The stand increment of a tree can be seen from the speed of growth (Simon, 2007). The growth rate of young trees is generally higher and when they are mature the growth rate will reach a plateau 
at one time.

\section{CONCLUSION}

\section{A. Conclusion}

Stand structure indicates that there was a difference between PSPs without and with treatment in each diameter class. General model of stand structure can be used to determine the shape of the stand structure of PSPs without and with treatment.

Growth of a stand is affected by the components of the growth, i.e. ingrowth, upgrowth and mortality. The rate of ingrowth, upgrowth and mortality varies between PSPs without and with treatment in each diameter class and length of time after harvesting.

Average annual diameter increment of trees on PSPs with treatment was $0.55 \mathrm{~cm} \mathrm{yr}^{-1}$, which is relatively slower than PSPs without treatment, where it was $0.60 \mathrm{~cm} \mathrm{yr}^{-1}$. It was affected by the type of silvicultural and environmental actions.

\section{B. Recommendation}

Future research related to the increment of the same species is required to produce a growth model, taking into account existing environmental factors.

\section{REFERENCES}

Buongiorno, J., \& Michie, B. (1980). A matrix model of uneven-aged forest management. Forest Science, 26(4), 609-625.

Buongiorno, J., Peyron, J. L., Houllier, F., \& Bruciamacchie, M. (1995). Growth and Management of Mixed-Species Unevedaged Forest in French Jura : Implication for Economic Return and tree Diversity. Forest Science, 14(3), 397-429.

Daniel, T. W., Helms, J. A., \& Baker, F. S. (1987). Prinsip-prinsip Silvikultur (Translation by $D$. Marsono) (2 ${ }^{\text {nd }}$ ed.). Yogyakarta: Gadjah Mada University Press.

Davis, L. S., \& Johnson, K. N. (1987). Forest Management. New York: McGraw-Hill Book Co.
Golley, F. B. (1983). 1983. Tropical Rain Forest Ecosystem : Structure and function. Amsterdam: Elsevier Scientific.

Kofod, E. O. (1982). Stand Table Projection for the Mixed Dipterocarp Forest of Sarawak, FAO/ MAL/76/008 (Working Paper No.11) (p. 13). Kuching: Forest Department.

Kramer, P.J. Kozlowski, T. T. (1960). Physiology of Trees. New York: McGraw-Hill Book Company.

Krisnawati, H., \& Wahjono, D. (2010). Effect of Post-Logging Silvicultural Treatment on Growth Rates of Residual Stand in A Tropical Forest. Journal of Forestry Research, 7(2), 112124.

Lal, A. B. (1960). Silviculture System and Forest Management. Dehra Dun, India: Jugal Kishore and Co.

Meyer, H. A. (1952). Forest Mensuration. Pennsylvania: Penn Valley Publishers.

Meyer, H. A., Recknagel, A. B., Stevenson, D. D., \& Bartoo, R. A. (1961). Forest Management. New York: The Ronald Press Company.

Oliver, C. D., \& Larson, B. C. (1990). 1990. Forest Stand Dynamics (p. 467). New York: Mc. Graw Hill, Inc.

Prodan, M. (1968). Forest Biometrics. Oxford: Pergamon Pres.

Simon, H. (2007). Metode Inventore Hutan. Yogyakarta: Pustaka Pelajar.

Suhendang, E. (1994). Penerapan Model Dinamika Struktur Tegakan Hutan Alam yang Mengalami Penebangan dalam Pengaturan Hasil dengan Metode Jumlah Pohon sebagai Suatu Alternatif Upaya Penyempurnaan Sistem Silvikultur TPTI. Bogor: Faculty of Forestry, Bogor Agriculture University (Unpublished).

Undaharta, N.K.E., Bramantyo, T. A. ., \& Siregar, M. (2008). Mean annual increment of Dysoxylum parasiticum (Osbeck) Kosterm. in "Eka Karya" Botanical Garden, Bali. Biodiversitas, 9(2), 280283. Retrieved from http://biodiversitas.mipa. uns.ac.id/D/D0904/D090408.pdf

Vanclay, J. K. (1995). Growth models for tropical forest: A synthessis of models and methods. Forest Science, 41(1), 7 - 42. 
Waring, R. H. (1987). Characteristics of Trees Predisposed to Die. Bio-Science, 37, 569 - 574.

Waring, R. H., \& Schlesinger, W. H. (1985). Forest Ecosystems, Concepts and Management. Orlando: Academic Press. 